\title{
The Main Factors of Yemeni Conflict: An Analysis
}

\author{
Adeb Abdulelah Abdulwahid Al-Tamimi \\ Department of Studies and Research in Political Science, Kuvempu University \\ Jnanashayadri, Shankaraghatta, Shivamoga, Karnataka, India, 577451. \\ Email: adebtamimi@gmail.com \\ Uddagatti Venkatesha \\ Department of Studies and Research in Political Science, Kuvempu University \\ Jnanashayadri, Shankaraghatta, Shivamoga, Karnataka, India, 577451. \\ Email: uddagattiv@gmail.com
}

\begin{abstract}
Yemen is an unsteady country with a long history of conflict and many complex issues that have led to the deterioration of the political, economic, and social situation. The conflict in its various stages began as an internal political struggle as a result of the people's grievances and the elite's competition for power and national wealth, in addition to other external factors. Hence, it is important to study the conflict factors in Yemen to understand the situation which in turn will help in providing solutions by decision-makers towards peace-making. Therefore, this study analyses the conflict factors in Yemen based on the political, economic, and social effects, in addition to the external interference effects. The research findings indicated that the conflict factors were not the only result of security or political issues but also presented by many socioeconomic problems as well as external factors, which have affected of the country since its unification.
\end{abstract}

Keywords: Yemen conflict; conflict factors; centralization; marginalization; governance

DOI: $10.36341 / j d p . v 4 i 2.1912$

\section{INTRODUCTION}

Yemen is one of the countries located in the Arabian Peninsula, which is characterized by a long history of conflict and many complex issues during which it has gone through periods of peace and prosperity, but it has not lasted. The crisis was exacerbating and expanding from time to time. These circumstances generally led to the worsening of the security and political position there and also had an impact on the economic and social spheres.

Yemen is confronting a unique concourse of crises. A continuing civil war and several political and tribal conflicts in the North, a Southern secessionist movement, and the last of them is the Houthi coup against the government and thwarting the transitional period. Even under the rule of the former Yemeni President Saleh, the central authorities in Yemen have never been powerful. In addition, through a delicate balance between the military and security establishment, clergy, and the major tribes, he was able to maintain his power (Boucek, \& Ottaway, 2010).

As one of the poorest Arab nations, Yemen is suffering from rapid population growth and one of the greatest growth rates in the world. But these high growth rates are more than the capacity of the state to meet its people's demands, which leads to more problems at the local level. Throughout history, Yemen, especially in the twentieth century, has faced many external endeavors 
to intervene in its state affairs. The global challenges, on the other hand, have hindered the country's growth process. Such problems have also plagued them at the domestic level. In 2009, the financial crisis increased the rate of poverty in several countries, including Yemen (Breisinger, et al. 2011).

It can be said that the conflicts that occurred in Yemen before the unification of its two parts were due to the political factor, which is the struggle of the political elites for power and governance. Accordingly, in this study, we will discuss the factors that led to the conflict in Yemen, in the period from after achieving unity until the present time. The subject of the present research is to identify and track the different political, economic, social, and cultural factors that are constantly in flux and evolve, and to do so specifically in the context of the Yemen conflict. To do this, the article focuses on, among other things, the social, political, economic, and cultural dimensions of the matter. These are the factors that nourished and bred the current war and made it the complex social, political, and cultural phenomenon that it is in Yemen today.

This article offers background information on Yemen's situation to clear the context in which the conflict emerged by describing and investigating the factors that led to this, Thus it is the framework for decision-makers to move forward in the process of peace-making in Yemen. The major contribution of this study:

(a) Taxonomy of the Yemen conflict factors based on the local political, economic, social and the external interference.

(b) Analysis the Yemen conflict factors based on their effects on the conflict.

Rest of the study is organized as the following: section 2 present the review of the related studies, section 3 offer the methodology which follows to achieve the objective of this study, section 4 provide a discussion of the conflict factors and section 5 which conclude the study.

\section{LITERATURE REVIEW}

Yemen has a lengthy history of complex turmoil and conflicts (Aboueldahab, 2019) resulting from political, economic, and social reasons. Yemen has not witnessed stability since the unification of its southern and northern parts, as political differences between the internal parties have caused instability and chaos, which subsequently led to conflict in the country. This section reviews the existing studies related to the conflict in Yemen. As Al-Tamimi and Venkateshe pointed out that the revolution of 2011 in Yemen has started as a result of the suffering of the Yemeni people for decades under a dictatorial regime that relied on the tribal card to ensure the continuity of its power. In addition to their discontent regarding the unemployment, economic decline, and corruption throughout the country (Al-Tamimi and Venkateshe 2020).

All attempts to improve the nation's "formal" institutions, according to Philips, culminate in the corruption patronage network becoming more powerful. Recognizing the significance of this network allows one to appreciate the nontraditional tasks that the Yemeni state has been able to perform to suppress and take advantage of a succession of crises for political purposes (Phillips 2017). Dingli argued that analytically examining Yemeni politics through the 
internal dynamics of tribal and patronage networks, and also the nature of the regime's and its constantly changing coalitions and crisis since unification, enables one to comprehend the regime's complicated and volatile structure and methods. As he argued, the use of purposefully generated chaos is considered the most crucial (Dingli 2013).

According to Ghoble the current situation is the result of a conflict between the top regional players, Saudi Arabia and Iran, as well as the stance of the US and Russia in changing dynamics. He assessed the ongoing hardship, emphasizing that the conflict is mostly driven by geoeconomic considerations and is not limited to the issue of regional hegemony (Ghoble 2019). Serr also claimed that the military situation among the conflict's actors is deadlocked, citing animosity, mistrust, and sectarianism as the motivations for their differences. Furthermore, an increase in the Saudi-Iranian fight for regional domination could result in the conflict escalating further (Serr 2017).

Through the review of the previous works mentioned above, it can be found that these studies are limited to some conflict factors such as regional competition, sectarianism, political and economic factors. In addition, due to prolonged conflict, which inevitably leads to the emergence of new factors that increase the intensity and complexity of the conflict. This limitation and research gap motivated us to provide a comprehensive analysis of the conflict factors in Yemen. Therefore, this study analyses the factors that led to the rise of the conflict between the local parties, which later developed through regional intervention.

\section{RESEARCH METHOD}

The paper adopts the descriptive research method to investigate the factors which led to the conflict in Yemen in order to obtain a better understanding of the nature of the Yemeni conflict that should be the basis of any peace process to resolve the conflict.

Data source and scope: the research relied on secondary data and resources, which include books, articles, and reports, in order to present a sufficient overview of the factors which led to the conflict in Yemen. The scope of the focus of this study involves the secondary data available during the instability period which was after the summer of the 1994 war until the current conflict.

\section{RESULTS AND DISCUSSION}

Political observers agree on the combination of factors that caused the social explosion known as revolts. The lethal combination of factors, combined with the oppressive and aggressive existence of regimes and the repression of individual freedoms, results in economic decline and government corruption (Cockburn 2011). For years, rising instability has led many to expect the eventual breakdown of Yemen. As the state spiraled into civil war, these predictions became true in late 2014. The dispute pits a coalition of the Houthis along with forces and militias faithful to the former president Saleh, against supporters and allies of the government overthrown by the Houthis in early 2015 (Juneau 2010). 
This section provides a description and an analysis of the main factors which caused the conflict in Yemen, according to the classification proposed in this research. This article classifies the conflict factors into two main factors. The first one is internal factors at the national level and the second one is external factors at the regional and international level. The internal factors include: 1) political, 2) economic and social. The external factors include: 1) geopolitical interests and competition for regional sovereign between Saudi Arabia and Iran, as shown in the figure.1 below.

Figure1 Taxonomy on factors of conflict in Yemen

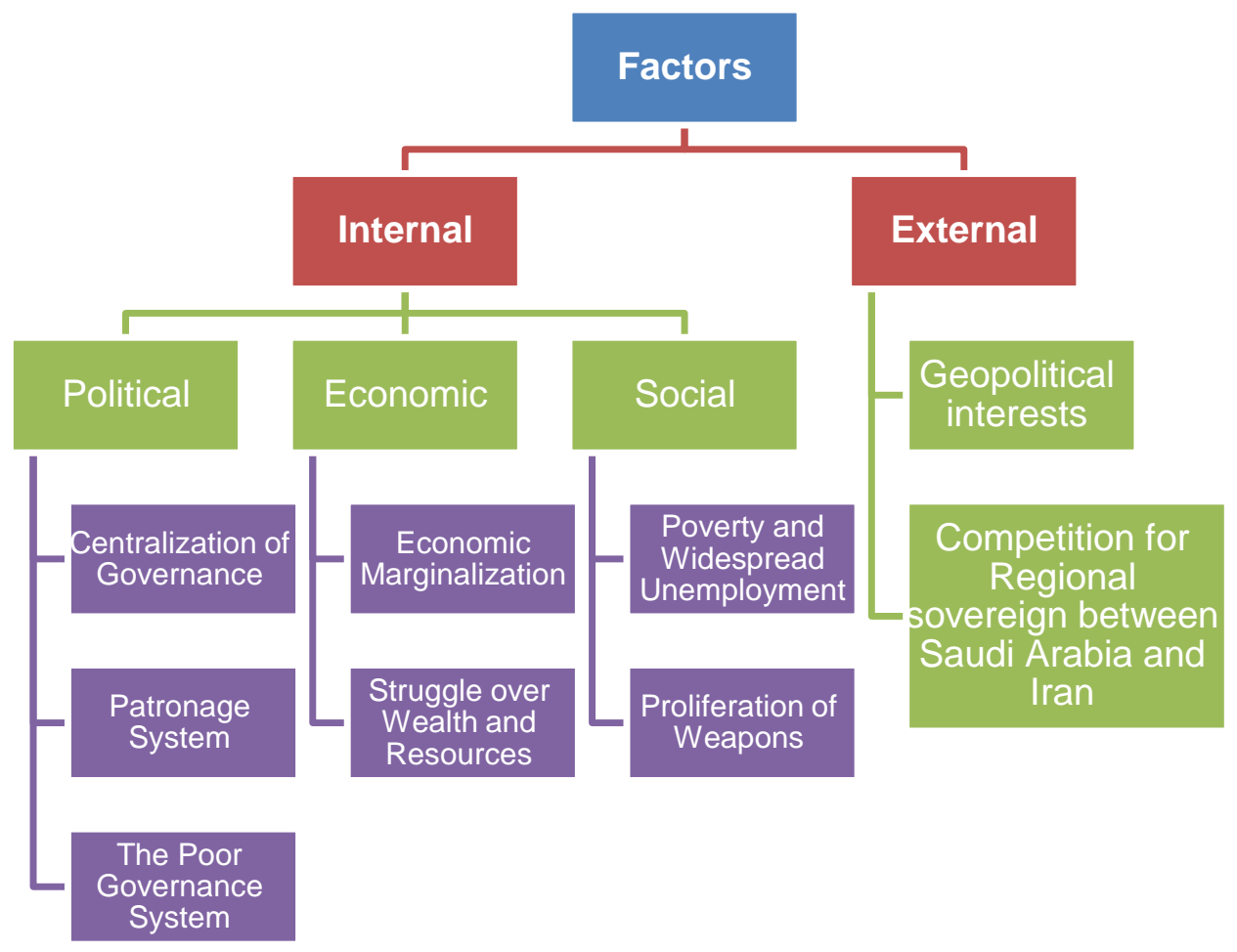

Source: authors' proposal

\section{Internal Factors}

The authors believe that the conflict in Yemen has internal factors which are the main reasons that lead to the current complicated situation. This section investigates and analyzes the political, economic, and social factors.

\section{Political Factors}

Theoretically, Yemen has a representative parliament and president, a multiparty system, an autonomous judiciary, and a democratically elected local government structure. However, political power is not created or transferred by these institutions. Alternatively, power and wealth are created and conveyed through a largely informal, yet profoundly textured network which based on tribal and regional patronage relations (Alley 2010a).

Internally, President Salih's strategy was to construct alliances of various parties and tribes. He had no clear political agenda, but whenever he could, he subsumed coalitions of various stripes, not hesitating to form new allies whenever it was convenient. He applied the same strategy to the foreign affairs 
of Yemen, establishing links with several of very distinct donors and sponsors. During the Cold War, that meant negotiating with both sides and disregarding ideology. Salih purchased Moscow's new military weapons and sent Yemenis for military coaching in the Soviet Union. Meanwhile, he persuaded the United States and several other Western countries as well as Arab Gulf Countries to provide generous economic assistance (Rugh 2015).

Centralization of governance: The previous regime depended on the system of central government and a pattern of unequal development, which influenced the subsequent development of the modern state of Yemen and led to the region's economic, social and cultural marginalization. Exploitative center-periphery relations, embodied in urban skewed economic policies that have triggered tensions that later endanger national unity, are an operating principle of this system (Salih 2013).

The government followed the same pattern of unequal development and developed economic plans that benefited the ruling party and its supporters. National wealth continued to be concentrated geographically in the center under this system, together with the severe accumulation of wealth in the hands of a few people associated with the regime and the growing severity of poverty in the other regions. These evolutions added to grievances and widened socioeconomic inequalities on a national scale.

Patronage system: In the mid-1980s a sea change took place in the political economy, where the central government in Yemen in 1986 took dramatic steps to increase direct taxation and regulate the private sector. The strict control of imports by the state was of particular significance. A radical change took place in the business class in Yemen and the traditional role of tribal elites through the regime's control of import licenses (Dresch, \& Paul, 2000).

Salih has entered dozens of tribesmen into the business community while traditional trading houses rose and fell based on their willingness to cooperate with the president and the new tribal business elite. In short, around this time, patronage networks extending from the President became a central part of the production and transfer of power. In reality, Saleh has established a profoundly organized network of tribal and regional patronage relationships (Alley 2010a). This unofficial system of patronage is a dynamic game of haggling between Saleh and his clients.

Since becoming President of North Yemen in1978, Salih's rule has relied on an unofficial system of patronage (Alley 2010a). The President immediately started after taking office to set his family members and close leaders of the Sanhan tribe, to which he belonged, in influential positions of military and security. In addition, Salih also worked to integrate powerful social elites, especially tribal shaykhs, into networks of patronage through direct subsidy, distribution of government positions, and ultimately access to the private sector, as well as coup-proofing the military-security apparatus through family and tribal appointments.

Repression has been used by the Yemeni regime, but President Saleh has been especially effective in selecting and exploiting alternate elites through a comprehensive patronage network (Phillips 2017). The inner circle of the regime, a clandestine group composed mostly of relatives of Saleh, operated the most sensitive military posts in the country and controlled its economy. The Yemeni state cannot be seized independently of this regime, because official 
roles will be minor to that of the actor in the network of Saleh. The patronage network of state money, mainly aid and oil revenues, was largely established and maintained by Saleh and used positions in the state to reward obedience or buy off dissenters (Phillips 2008). In addition, despite of Saleh was impeached in 2011, most of his regime continued to function (Alley 2013). This included elite performers, but also managers at lower levels who owed Saleh's network their jobs as public servants.

The energy sector is a profitable source of state revenue, which the president uses for his patronage networks. Oil revenues constituted 90 percent of the export income of the country and nearly $75 \%$ of the budget of the central government (Gerner \& Tordo 2007). These revenues fund most of the government expenditures, which include civil servants and military wages. Moreover, the President is able distribute access to oil concessions, as well as the ability to market the Yemeni government's share of produced crude oil to influential customers. In short, domestic oil production and diesel subsidies represented a massive expansion of government wealth, and hence an expansion of the President's patronage networks.

In addition to the increasing economic dominance, Salih founded the General People's Congress (GPC) in 1982 as a quasi-party organization, which integrated a wide range of social groups and political trends. "The GPC identified itself as an explicitly non-partisan, nationalistic organization that objectives were "state-building, democracy, constitutional ruling, modernization, and the creation of military-security establishments (Carapico 2007).

Undoubtedly that the inclusiveness of the patronage system in Yemen has contributed to the longevity of the ruling regime. Any kind of gain is earned by most influential elites, whether they are allied with the governing GPC or members of the formal opposition, and thus have some interest in maintaining the status quo. Until recently, the creation of a radical or pragmatic opposition with the willingness or ability to impact regime change has been hampered by this ecumenical distribution.

The absence of a governance system: weakness of the system of government, as the state's presence, was confined to urban areas and major cities, while peripheral, tribal and rural areas, the state's presence was weak and near nothing. In Yemen's countryside, where most of the citizens are concentrated, the government's presence was represented through the local elite who have connections to the Saleh's network. Although local elites frequently have a tribal history, the Yemeni state's failure to monopolize conflict or penetrate the periphery can therefore not be reduced to a fight between modern and traditional modes of government. Rather it was the consequence of Saleh's system of governance focused on polarization and patronage that funded by the state (Clausen 2018).

Yemen's historic bad governance has driven the population to search out services from other providers and this void has been filled by the growing extremist groups under this situation. Where these groups provided some services and thus entrenched the idea that the government is unable to meet the needs of these areas. It was therefore argued that the support of extremist groups was based on its ability to fill the void of security and governance left by the government, rather than any clear support for its ideologies (ICG, 2017). In addition, many people in Yemen have funded these groups out of sheer 
dissatisfaction with the government's inability to provide services and better governance (al-Dawari 2014).

On the one hand, the resource base of the regime is diminishing, especially as declining oil revenues threaten the budget of the central government (EIU 2010). On the other hand, the President has decided to restrict the distribution of Fortunes and important leadership positions in government institutions within his family particularly his son and nephews. In addition to these two destabilizing tendencies, a coalition of grassroots leaders coordinating the southern protest campaign "Hirak" in the territories of former South Yemen were also unable to effectively co-opt the President. In summary, the shrinking resource base, the perceived straitening of the distribution of patronage within the family of the President, and the presence of a large number of grassroots leaders beyond the paradigm of patronage are important reasons for the elite's aversion to the regime that led to the collapse of his regime in 2011.

\section{The Economic Factors}

From a socio-economic viewpoint, Yemen is one of the world's least developed countries (LDCs), with an average per capita GDP (PPP) of US\$2,800 in 2015, 194 out of 228 countries. More than half of the Yemeni population is poor and has a low rate of adult literacy, estimated at $70 \%$ overall and just $55 \%$ among women. This is paired with a high $2.47 \%$ annual population rise (CIA, 2007). Moreover, the Government of Yemen relies highly on oil revenues, which represent more than $77 \%$ of the country's total exports. In economic growth and average population enrichment, this heavy oil dependency has never been translated, differentiating the country from all the other Rentier States of the Arab Peninsula mainly due to an increased population and reduced oil extraction.

The country's reliance on food imports is another key economic problem, as the agricultural sector is the main source of subsistence and the main demand for primary food commodities is not adequate. The country's chronic water shortage is the key difficulty in agricultural production, "Its renewable sources are estimated to supply 2.1 billion cubic meters per year while current annual extraction is estimated at 3.5 billion cubic meters" (Lackner 2014). This means that Yemen is depleting its water sources at a stunning pace.

Financial pressures are one of the most important motivating factors and drivers of conflict, particularly when corruption at the hands of the ruling and social elite is introduced. These tendencies have resulted in the economic impoverishment of the majority of the population, a fact dramatically illustrated by the staggering rise in food prices and high unemployment rates, especially among young people under the age of 25 , who make up approximately $65 \%$ of the total population. This is in marked contraindication to the continuing enrichment of the governing elites, who have managed to amass an immense amount of wealth through corruption (Engin 2011).

Economic marginalization: the economic and political marginalization of the Saada region, the unequal distribution of natural resources and political participation, and religious discrimination against its Zaidi population, some scholars and researchers argue, have given fertile ground for the Houthi movement to take root and flourish (Brandt, 2017). While in reality, all of the 
aforementioned grievances have been exposed to the Saada governorate and the various groups of the people in the country, except for the political elite and those who are included in the patronage system. It is not logical to identify with all the grievances in a particular region apart from other regions that may have been subjected to more injustice.

Transparency International (TI) classified Yemen as one of the world's corrupt states in 2010, and the Middle East region's second most corrupt. Patronage and cronyism haunt Yemen in almost every facet of the industry. To create and broaden his patronage-client relationships, Saleh used his political party, the General People's Congress (GPC). A GPC membership is a mark of "loyalty" to the regime, and it is composed of national committees that represent central government objectives as a way of receiving government benefits (Alley 2010b).

Yemen faces a laundry list of development problems in addition to corruption and has not found the balance between growing its potential and supplying basic commodities to the public. Generally, the state of Yemen does not provide its 23.5 million population with basic services, which is increasing at a rate of 2.7 percent per year (Alley 2010b). To make the problem worse, in the next decade, its oil revenue, which accounts for most of the state's income, will expire. Another rapidly dwindling natural resource is water, and it is still recognized as Yemen's biggest threat (Ward 2014).

Struggle over wealth and resources: The battle between the "center" and the "periphery" for economic resources and political autonomy is a constant, endemic characteristic of Yemen's policy. Approximately 28 million Yemenis of various affiliations are competing for the scarce resources in their country. The lack of water is a source of tension in society and a possibly growing obstacle to the future is at the forefront of these environmental and resource problems. Water scarcity has led to the spreading of waterborne illnesses on an unimaginable level across the country. As a consequence, Yemen's shortage of sanitation and safe water accounts for $50 \%$ of the mortality of children and babies (Ward, 2014). In addition, small-scale farming utilizes nearly $90 \%$ of Yemen's water supply, but the agricultural sector accounts for just $6 \%$ of the state's Gross Domestic Product (GDP). Part of the issue is that the planting of Qat, a plant which a large number of Yemenis have chewed, accounts for around $50 \%$ of the agricultural sector's water use.

Economic difficulties are not limited to its lack of water in Yemen, it is a low-income nation, heavily dependent on diminishing oil supplies. Nearly $25 \%$ of its GDP is focused on oil sales, and terrorist attacks regularly threaten the country's pipelines. Yemen is also suffering from food shortages and a high unemployment rate. The rate of youth unemployment is projected at $33.7 \%$ in a nation (Rogers, 2012), with a strong population growth rate of $2.3 \%$ (The World Bank, 2019). These economic problems are further compounded by weak governance, corruption, and the country's uncertainty and insecurity. In gun ownership, Yemen also ranks second globally (Rogers 2012).

\section{The Social Factors}

There are different key problems on the social side of the conflict factors, such as complex tribal and sectarian systems that appear to crystallize society and discourage social improvements of the more indigent and favor corruption and 
tribal patron-client frameworks. The fact that 40 percent of the total population is under the age of fourteen is another key issue, which, combined with a poorly organized school system, is the ideal atmosphere for terrorist organizations to promote and grow their core membership.

The Yemeni countryside is marked by a lack of government facilities, a shortage of water, electricity, and employment prospects. In addition to the lack of awareness and widespread poverty in those areas, many youths join extremist groups to earn a living, as well some local dignitaries who have long been ignored by the central government for a long time and found their desire for a public status met by becoming a part of those groups.

Finally, a study of the reasons underlying the crisis in Yemen could not disregard the reality of the central government only has little influence over the state's territory. Much of the central government continues limited to the big urbanized regions. Service delivery to rural areas is highly challenging and a population of almost three-quarters lives outside the cities. The tribes continue to play a strong role in filling the void created by the state and have penetrated the institutions of the state. They have important positions in Yemen's legislative and administrative bodies, in the military forces, in the safety apparatus, and in the overall political structure. Therefore, strategic decision-making involves negotiation, settlement, and barter in the sense of relationships that are continually changing (Ahmed 2015).

Poverty and widespread unemployment: the population increase has produced youth with no employment prospects. Yemen's government was unable to provide work or a purposeful education. There was also an underdevelopment of the private sector. As a result, there was much youth in a desperate situation. Their desperation generated grievances in a collapsed state context for the greed-driven elites, who desired to follow their own ambitions, with readily accessible human resources. Eventually, the elites took advantage of this chance and structured the youths in the way they were drawn to them.

In Yemen, the existence of the labor force poses a paradox of sorts. Yemen is suffering from a debilitating rate of illiteracy. An estimated $43 \%$ of Yemenis live below the poverty line and a whopping $40 \%$ of Yemenis have jobs (Fatah, 2011). In pursuit of works, a large number of Yemeni men travel abroad. Projects for local development are unmanaged and village societies remain heavily reliant on emigrant workers' remittances. These employees can return home with savings invested in small businesses such as shops, but rising inflation renders these business ventures economically unviable. From the 1980 s to the present, importing food has been cheaper than growing it.

The proliferation of weapons: The availability of weapons has intensified the conflict in Yemen. The citizens of Yemen were well-armed. The availability of arms, combined with all the grievances and conflicts alluded to above, culminated in a full-scale civil war.

Yemen is commonly cited as one of the most highly armed societies, in terms of per capita, in the world. Despite entirely fabricated, very unplausible, estimates of 50-60 million small and light weapons in circulation, more logical evaluations indicate something for every two civilians in the order of 10 million or less small arms or approximately one firearm. A recent Yemen National Small Arms Ownership Survey found that $61 \%$ of respondents registered guns in their households. Weapons proliferation was described by Rashad al-Alimi, 
Deputy Prime Minister for Security and Defense Affairs, and former Interior Minister, as one of Yemen's four 'security challenges'; the others were terrorist attacks, border protection, and 'poor state loyalty.' The availability of weapons is often cited as being significantly linked to the rapid escalation of armed conflict in Yemen (YAVA 2010).

\section{The External Factors}

This section investigates and analyzes the factors at the regional and international level in two aspects as the following:

\section{Geopolitical Interests}

At the external stage, Iran, Saudi Arabia, the GCC, the United States, the United Kingdom, and France have geopolitical interests in Yemen. The security issue is of great importance for Saudi Arabia, counter-terrorism for the US and the UAE. In addition, US priorities include a secure Yemeni government and free movement to the Bab al-Mandeb, as well as a secure Saudi border (Laub 2015).

Iran and the Houthis share similar geopolitical interests. Iran tries to challenge the region's Saudi and US dominance, and the Houthis are the main opposition in Sana'a to Hadi's Saudi-and US-backed government. However, It should be taken into account that the participation of multiple external actors in Yemen does not change anything in the circumstances in which the conflict is still closely linked to domestic dynamics.

The US position is to combat terrorists to stabilize the country, to defeat the proliferation of Iran in the region, to protect the Saudi border, to enforce the results of the NDC and SC Resolution 2216, and to ensure the safe and free passage of Bab al-Mandeb. The interest behind the latter, though is financial. On the one hand, the US sells approximately $\$ 110$ billion worth of weaponry to the Saudis, and on the other, via the Bab al-Mandeb checkpoint, 4.7 million barrels of oil per day transit (Kleemann 2019).

The continued and expanded 'targeted killing' policy pursued by the United States of America, with the express consent of the State of Yemen, against designated Al-Qaeda targets, which were mainly carried out by the use of drones, was an additional external factor that helped destabilize Yemen (Open Society Justice Initiative. 2015). As one analyst recently noted, "journalistic and think-tank reporting has tended to overlook the deleterious impacts on state sovereignty and regime legitimacy of US counter-terrorism airstrikes against al-Qaeda targets."

\section{Competition for Regional Sovereign between Saudi Arabia and Iran}

Although the conflict between Saudi Arabia and Iran is sometimes alluded to as the Sunni-Shia war, their competition is motivated by their regional interests rather than a sectarian one. In the Middle East, both nations compete to maximize their spheres of influence, making a rather turbulent area even more chaotic. Tehran is attempting to export its thoughts to countries with a large Shia sect, such as Lebanon, Iraq, and Saudi Arabia's Petroleum eastern areas. While Saudi Arabia and the other Arab concerned perceive the propagation of the revolutionary agenda of Iran in their regions as seriously dangerous, it can provoke disorder within the society, as they worry. 
Up to now, both Saudi Arabia and Iran have avoided military confrontation directly. Rather, they attempt to exploit current tensions in the region for their benefit by proxy wars, both regimes fight for dominance. In the regional rivalry between Saudi Arabia and Iran, Yemen is not the only frontline; both support opposition groups in Iraq, Syria, Lebanon, and Bahrain. However, the Yemen dispute is central to the Saudi-Iranian's force struggle. It has strategic importance for Saudi Arabia, as they share long borders; but Tehran succeeds in holding the Saudis occupied with little effort and putting considerable economic, political, and military pressure on them (Gidon \& Peter 2016).

Since the USS Cole attack in 2000, relations between the US and Yemen have focused on counterterrorism. The pressure from Washington to crack down on terrorist networks causes Yemen to participate in a risky balancing act. On the one side, perceptions of alignment with the U.S. are extremely unpopular with the Yemeni public, placing the government at risk of stoking an already volatile environment. The government, on the other hand, wants greater assistance and support, especially in capacity-building for the army and security forces. The difficult relations that Yemen has with Saudi Arabia and the United States are significant. Overt interference by either the United States or Saudi Arabia is highly unpopular since distrust and suspicion of foreign actors are extremely high in Yemen (Juneau 2010).

In 2015, it became evident that Salafi groups emerged in Yemen as an effective fighting force and that the United Arab Emirates was their main external supporter (UAE). Essentially, in the view of the speaker, the UAE has built a whole new patronage network in Yemen and militarised the Salafist movement.

\section{DISCUSSION}

Many factors explain why the conflict arising in Yemen. At the same time, The internal influential actors 'competition for power and resources is emerging as a catalyst that has led, along with other factors, to the conflict. Also, the prominent role of the strategy of regional and international powers cannot be ignored, especially after the outbreak of the war, whether through direct intervention or any form of support, which can be considered a factor in the raging and continuation of the conflict.

It is extremely important to note that local political, social, and economic grievances are the key drivers of the conflict and that the rise of the Houthis was enabled by the assistance of former President Saleh and his network of tribal and military supporters, as well as by their exploitation of public disgruntlement with the transitional government. This is a key issue for such an unstable state that is complaining about weak of centralized power and the lack of resources. The confluence of these factors has made Yemen an area that is insecure and dangerous, providing fertile ground for extremist groups and ideas.

Furthermore, it must be said, Yemen remains to face challenges from systemic development issues that inevitably worsen the political crisis recently and in the past. The important development challenges are high poverty rates 
and illiteracy, diminishing water supplies and a rapid increase unemployment due to high population growth coupled with economic decline.

The majority of the citizens of Yemen have genuine grievances. Basic services such as security, stability, education, health, and employment services have been neglected by the government. Additionally, the government has used military power to suppress citizens. In other words, Failure to provide Public Services lead to ignorance and backwardness. The increase in the number of unemployed youths in Yemen, which leads to fuel and continue the conflict by employing unemployed youth.

\section{CONCLUSION}

Yemen is a troubled country that suffers from many problems, most of which were in both parts of the country and it was inherited by the state emerging from the unification of 1990. The Republic of Yemen was created as a result of an incorrect unification process, as differences emerged between the leaderships of the two sides, which resulted in the civil war in 1994, in which the northern and southern pro-unification powers were victorious, due to many factors, that resulted in increasing dissatisfaction among the other southerners.

A synergy of negative factors characterized the period from 1994 to 2010 such as the narrowing of political liberties, increasing poverty, the decline in state revenue, and economic recession. A small faction, consisting of relatives and close associates surrounding President Ali Saleh, has gradually monopolized political influence. With the government failing to take the required steps to reform the security, fiscal, health, and education sectors, a community's well-being is often left to the people themselves. From this viewpoint, the precarious security position that results from the state's failures detrimentally affects the capacity of a society to evolve.

To sum up, this research dealt with the conflict in Yemen since the achievement of the unity between its two parts, focusing on the factors that led to instability in the country. This study presented a new classification of the factors of the conflict in Yemen, in terms of the internal political, economic, and social effects and the impact of external interventions as well. In addition to analyzing these factors and their impact on the conflict since the unification of the country.

Consequently, this study found that the conflict in Yemen began mainly an internal dispute, sparked by domestic grievances and domestic power and resource rivalry. Which exacerbated and later expanded to form external factors due to external interventions. This study can impact future researches in terms of understanding the factors and their effects on the conflict in Yemen, as well as providing a vision for decision-makers about the causes and effects of the conflict, through which a comprehensive peace plan can be built for the country.

\section{REFERENCES}

Aboueldahab, N. 2019. Reclaiming Yemen: The Role of the Yemeni Professional Diaspora. Brookings Doha Center, Analysis Paper. 
Ahmed, A. S. 2015. "Yemen in crisis- What role for the EU". Policy Department DG External Policies.

Al-Dawari, N. 2014. "Tribes and AQAP in South Yemen". Atlantic Council.

Alley, A. L. 2010b. "Yemen's Multiple Crises." Journal of Democracy 21(4), pp. 72-86.

Alley, A. L. 2010a. "The rules of the game: unpacking patronage politics in Yemen". The Middle East Journal, 64(3), 385-409.

Alley, A. L. 2013. "Tracking the 'Arab Spring': Yemen Changes Everything... And Nothing". Journal of Democracy, 24(4), 74-85.

Al-Tamimi, A. A. A., \& Venkatesha, U. (2020). ARAB SPRING IN YEMEN: CAUSES AND CONSEQUENCES. Shodh Sarita, 7(28), 59-63.

Boucek, C. \& Ottaway, M. 2010. "Yemen on the Brink". Washington, DC: Carnegie Endowment for International Peace.

Brandt, M. 2017. "Tribes and politics in Yemen: A History of the Houthi conflict". Oxford University Press.

Breisinger, C., Diao, X., Collion, M-L., \& Rondot, P. 2011. "Impacts of the Triple Global Crisis on Growth and Poverty: The Case of Yemen". Development Policy Review 29(2):155 - 184.

Carapico, S. 2007. "Civil society in Yemen: the political economy of activism in modern Arabia". Cambridge University Press.

CIA, 2007. "The World Factbook: Yemen", www.cia.gov

Clausen, M. L. 2018. "Competing for control over the state: The case of Yemen". Small Wars \& Insurgencies, 29(3), 560-578.

Cockburn, A. 2011. "The tweet and revolution". Archived from the original on, 02-27.

Dingli, S. (2013). Is the failed state thesis analytically useful? The case of Yemen. Politics, 33(2), 91-100.

Dresch, P., \& Paul, D. 2000. "A history of modern Yemen". Cambridge University Press.

Economist Intelligence Unit (EIU). April 2010. "Country Report, Yemen". p. 11.

Engin, K. 2011. "The Arab Spring: The 5.0 Democracy Wave". Hurriyet Daily News.

Fattah, K. 2011. "Yemen: a social intifada in a republic of sheikhs". Middle East Policy, 18(3), 79.

Gerner, F., \& Tordo, S. 2007. "Yemen-A natural gas incentive framework" (No. 40099, pp. 1-182). The World Bank.

Ghoble, V. T. 2019. Saudi Arabia-Iran Contention and the Role of Foreign Actors. Strategic Analysis, 43(1), 42-53.

Gidon, W. \& Peter, S. 2016. "Cold War in the Gulf". International Reports.

International Crisis Group (ICG). 2017. "Yemen's al-Qaeda: Expanding the Base". ICG Report, 174.

Juneau, T. 2010. "Yemen: Prospects for State Failure-Implications and Remedies". Middle East Policy, 17(3), 134-152.

Kleemann, S. 2019. "The Forgotten War: Yemen". University Press Potsdam. Lackner, H. (Ed.). 2014. "Why Yemen matters: A society in transition". Saqi. Laub, Z. (2015). "Yemen in Crisis". Council on Foreign Relations.

Open Society Justice Initiative. 2015. "Death by Drone - Civilian Harm Caused by U.S. Targeted Killings in Yemen". Report. 
Phillips, S. G. 2008. "Yemen's Democracy Experiment in Regional Perspective: Patronage and Pluralized Authoritarianism". New York. Palgrave MacMillan.

Phillips, S. G. 2017. "Yemen and the politics of permanent crisis". Routledge.

Rogers, S. 2012. "Gun homicides and gun ownership listed by country". The Guardian.

Rugh, W. A. 2015. "Problems in Yemen, domestic and foreign". Middle East Policy, 22(4), 140-152.

Salih, K. E. O. 2013. "The roots and causes of the 2011 Arab uprisings". Arab Studies Quarterly, 35(2), 184-206.

Serr, M. 2017. Understanding the War in Yemen. Israel Journal of Foreign Affairs, 11(3), 357-369.

The World Bank, 2019. "Population Growth (Annual \%)," https://data.worldbank.org/indicator/SP.POP.GROW.

Ward, C. 2014. "The water crisis in Yemen: Managing extreme water scarcity in the Middle East". Bloomsbury Publishing.

Yemen Armed Violence Assessment (YAVA). 2010. "Fault lines: Tracking armed violence in Yemen". Small Arms Survey. 